\title{
Usefulness of the working conditions and health survey in central America in prevention. Author response to comments by Jensen
}

We appreciate Dr Jensen's comments ${ }^{1}$ on the Central American Survey on Working Conditions and Health (ECCTS $)^{2}$ and his concern that our sampling methodology may have produced biased results. The ECCTS has broadly followed the methodological criteria of the European Working Condition Survey (EWCS). ${ }^{34}$

Of note is that, to estimate prevalence of exposures to different working conditions, the EWCS is applied every 5 years to a representative sample of only 1000 workers in the majority of European countries. The ECCTS had double the number, that is, 2000 per country. However, we acknowledge that a larger sample is better and, in fact, some European countries have started to increase their sample size.

To achieve representativeness, a national population sample must be properly spread over geographic sub-areas and population sub-groups. The random selection of a large number of census segments, proportional to the respective populations of the departments or provinces, accounted for geographic regions and levels of urbanisation, similar to the stratified procedures in the EWCS. In addition, we applied weights for sex, age and economic sector to each individual in the national samples to correct 
for differences in the sample with the underlying national working population with regard to these key socio-demographic parameters. Finally, for regional comparisons we applied an additional weight to adjust for the population size of the different countries. However, unlike the EWCS, we did not adjust for type of industry and occupation because the latter information was not always available from the census. As Dr Jensen points out, this would have been a more ideal approach.

The ECCTS is a first experience in central America and, as such, prone to improvements. Despite limitations, the results from the central American survey provide a first, baseline measure about specific working and employment conditions that allows for future monitoring across countries and serves as a useful tool for prevention. Further analysis, comparing prevalence of exposures among countries, has to be properly adjusted by economic activity and job category. All are available in the dataset upon request.

In conclusion, the first ECCTS represents a key step towards the development of a permanent information system for informed regional and national planning of preventive policies. ${ }^{5}$ The experience gained in the first central American survey will allow improvements in future surveys.

Fernando G Benavides, ${ }^{1}$ Catharina Wesseling, ${ }^{2}$ George L Delclos, ${ }^{3}$ Sarah Felknor, Javier Pinilla, ${ }^{5}$ Fernando Rodrigo ${ }^{6}$

${ }^{1}$ Center for Research in Occupational Health, Pompeu Fabra University, Barcelona, Spain

${ }^{2}$ Program on Work, Environment and Health in Central America (SALTRA), Universidad Nacional, Heredia,

Costa Rica

${ }^{3}$ Department of Epidemiology, Human Genetics and Environment, The University of Texas School of Public Health, Houston, Texas, USA

${ }^{4} \mathrm{NIOSH}$, Atlanta, Georgia, USA

${ }^{5}$ Instituto Nacional de Seguridad e Higiene en el Trabajo, Madrid, Spain

${ }^{6}$ Ergalog, Valencia, Spain

Correspondence to Professor Fernando G Benavides, Center for Research in Occupational Health, Pompeu Fabra University, Doctor Aiguader, 80 Barcelona 8003, Spain; fernando.benavides@upf.edu

Correction notice The second affiliation has been updated since published Online First.

Competing interests None.

Provenance and peer review Not commissioned; internally peer reviewed.

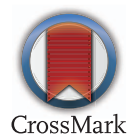

To cite Benavides FG, Wesseling C, Delclos GL, et al Occup Environ Med 2015;72:236-237.

Received 30 October 2014

Accepted 8 November 2014
Published Online First 27 November 2014

\section{CLinked}

http://dx.doi.org/10.1136/oemed-2014-102623

Occup Environ Med 2015;72:236-237.

doi:10.1136/oemed-2014-102665

\section{REFERENCES}

1 Jensen OC. Comment: working conditions and health in Central America: a survey of 12024 workers in six countries. by Benavides FG et al. Occup Environ Med 2015:72:236-7.

2 Benavides FG, Wesseling C, Delclos GL, et al. Working conditions and health in Central America: a survey of 12024 workers in six countries. Occup Environ Med 2014;71:459-65.

3 European Foundation for the Improvement of Living and Working Conditions. Fifth European Working Conditions Survey - Overview report. http://www. eurofound.europa.eu/publications/htmlfiles/ef1182.htm (accessed Oct 2014).

4 Gallup Europe. 5th European Working Conditions Survey's Weighting Report. Working document for The European Foundation for the Improvement of Living and Working Conditions. 2010. http://www.eurofound. europa.eu/surveys/ewcs/2010/weighting.htm (accessed Oct 2014).

5 Wegman DH, Hogstedt C. If it's not counted it didn't happen! Occup Environ Med 2014;71:457-8. 

health survey in central America in prevention. Author response to comments by Jensen

Fernando G Benavides, Catharina Wesseling, George L Delclos, Sarah Felknor, Javier Pinilla and Fernando Rodrigo

Occup Environ Med 2015 72: 236-237 originally published online November 27, 2014 doi: 10.1136/oemed-2014-102665

Updated information and services can be found at: http://oem.bmj.com/content/72/3/236.2

\section{These include:}

References This article cites 2 articles, 2 of which you can access for free at: http://oem.bmj.com/content/72/3/236.2\#BIBL

Email alerting service

Receive free email alerts when new articles cite this article. Sign up in the box at the top right corner of the online article.

\section{Notes}

To request permissions go to:

http://group.bmj.com/group/rights-licensing/permissions

To order reprints go to:

http://journals.bmj.com/cgi/reprintform

To subscribe to BMJ go to:

http://group.bmj.com/subscribe/ 